\title{
6 \\ Judicial Review of Administrative Action
}

Procedure

Judicial review of administrative action is a major part of the work of the administrative courts. As was pointed out in Chapter 4, the role of the Conseil d'Etat is most typically as the review court for the work of the cours administratives d'appel and the tribunaux administratifs. In French terminology, it is the court of cassation (quashing) rather than the court of appeal. But, like the civil and criminal Cour de cassation in private law, it sets the approach the other courts are to follow, and it interprets the major points of law either by way of avis or by review after the lower courts have decided a matter.

Judicial review is about ensuring the legality of the actions of the administration. Unlike supreme courts in some parts of the world, such as the Indian subcontinent, French administrative courts are essentially reactive - they cannot begin proceedings of their own initiative (suo moto). The French judge is required to confine herself to the claim made and cannot judge outside it (ultra petita). Thus, the judge cannot annul a decision in its totality when only certain parts are challenged in the claim. ${ }^{1}$ The main exception here are the moyens d'ordre public, grounds which exist in the public interest, and which the judge can raise of her own initiative, provided she then submits these to the observations of the parties.

The extent to which the administrative courts are a major forum in which the decisions of the administration are challenged depends on the ease with which actions can be brought and the character of the remedies that can be granted, as well as their enforcement.

1 CE 27 July 2005, Département d'Essonne, no. 267499: the lower court annulled the whole decision placing the claimant on leave from December 2000, when she only challenged its effects from April to December 2001. 


\subsection{WHO CAN CHALLENGE AN ADMINISTRATIVE DECISION?}

The basic principle in French law is that anyone with a direct and certain interest can challenge an administrative decision which affects him or her. Individuals can bring an action which affects them as individuals, as members of a group, as users of a public service or for a collective interest. In a number of situations, associations can bring challenges. Because actions in the courts are not just the defence of rights, as in private law, but are designed to maintain the legality of public decision-making, the requirements for having a legitimate interest in bringing an action are much less than in private law. On the other hand and contrary to other jurisdictions, the action has no suspensive effect until the court rules on the case.

Interests as an individual can arise either because you are the person to whom the administrative decision is addressed - for example, the refusal of planning permission - or because your personal situation is affected. To be affected, there must be something in the decision which changes your legal situation. A simple example is where your neighbour is given planning permission. So giving planning permission for building a cinema complex to a rival was not a sufficient interest to justify other cinema owners challenging the permission. ${ }^{2}$ But the standard went so low that actions against planning permission became a lucrative sport to gain money for withdrawing a claim - so lucrative that the legislator decided in 2018 to set for this area a stricter standing for action. Article 6oo-1-2 of the Planning Code (Code de l'urbanisme) provides that an individual may only challenge the award of planning permission to another if it is liable to affect directly the conditions of his occupation, use or enjoyment of the property. On the other hand, civil servants are entitled to challenge the appointment of someone else to a category to which they belong or who might advance into that category. Thus, in Lot in 1903, appointment to the grade of archivist-palaeographer was limited to the holders of particular diplomas. ${ }^{3}$ It was held that Lot was entitled to challenge the appointment of someone else as director of the archives for breach of the rules on appointments (though in the end no breach was found on the facts). Similarly, in Rodière, it was held that a civil servant could challenge the appointment of others to posts in grades below his, because their appointment to those grades entitled them to compete with him in future promotions. ${ }^{4}$ Financial interests can also be sufficient to give a person an

2 CE Sect. 13 March 1987, Société albigeoise de spectacles, no. 55525, Leb. 97.

3 CE 11 December 1903, Lot, no. 10211, S 1904.3.113 note Hauriou.

4 CE 26 December 1925, Rodière, no. 88369, S. 1925.3.49 note Hauriou. 
interest. For example, in Cook, a firm of travel agents was able to challenge successfully a municipal by-law which subjected excursion charabancs to the same (stringent) regulations as taxis. ${ }^{5}$ A simple camper had standing for action against a mayoral ban to camp even though he had never set foot in the city at stake. $^{6}$

Interests as member of a group arise where several individuals are affected by the same decision of a public body. Art. L 77-10-3 CJA provides that one person may sue on behalf of a group to annul a decision or to bring an action for state liability.

Interests as users of a public service are a kind of group action. The individual is personally affected as a user, but he or she is really one of a group. In Croixde-Seguey-Tivoli, a leading public lawyer, Léon Duguit, formed his neighbours into an association to protect the interests of his neighbourhood in Bordeaux. ${ }^{7}$ They then complained that the private company running the tramway concession had decided to withdraw the service to their area in the reorganisation of the service from horse-drawn to electric trams. The prefect rejected their complaint. The association was allowed standing, even though it was unsuccessful in its challenge to his interpretation of the terms of the concession. A good example of a user successfully challenging the costs of a public service is Wajs. ${ }^{8}$ Here Mme Wajs, a motorway user, challenged the Minister's approval of toll charges imposed as a result of a concession to run a motorway. These included an obligation for the toll road company to pay for policing, which was held to be unlawful, and so the decree was annulled.

Interests of associations are less readily accepted because the Conseil d'Etat has not wanted to permit an actio popularis, but it does see the advantage of more orderly and competent challenges brought by associations, rather than by a series of random individuals. Reformed in 2017, art. L77-10-4 CJA provides that associations which have been registered for at least five years may bring actions to protect interests identified in their statutes. This is narrower than the situation of users of a public service in Croix-de-SegueyTivoli, where the association was set up to challenge the changes in tram services, but it was the first time French law introduced class actions. It applies to claims in relation to discrimination, the environment and public health, where there are special rules. The purpose of the rules in the CJA are to ensure an orderly use of litigation and to prevent series of cases being introduced.

\footnotetext{
CE 5 May 1899, Cook et Fils, nos. 91926, 91927, D. 1900.3.218.

CE, 14 February 1958, Abisset, no. 9999.

7 CE 21 December 1906, Syndicat des propriétaires et contribuables du Quartier de Croix-deSeguey-Tivoli, no. 19167, D. 1907.3.41 concl. Romieu.

8 CE Ass. 30 October 1996, Mme Waijs et Monnier, no. 136071, 142688, Leb. 327.
} 
A frequent example of actions by associations is the challenge by public-sector trade unions to civil service appointments and promotions. For example, in Syndicat de la Magistrature, Molins, the head of the Minister of Justice's private office, was appointed to the rank of avocat général at the Cour de cassation, but he never exercised his functions before he was appointed two years later as prosecutor at the TGI Paris. ${ }^{9}$ The arrangement was designed to qualify him for the position he took up when he left the Minister's office. The association was able to protect its interest in the legality of the appointment process in that it affected the interests of its members which it was formed to defend. More generally, professional associations can bring actions to protect the interests of their members. But it was explained in Syndicat des PatronsCoiffeurs de Limoges that the association must bring an action that relates to its collective interests and cannot bring an action relating to an individual, except by authorisation. ${ }^{10}$ So it could challenge a regulatory decision affecting its members, but it could not challenge the refusal of the prefect to grant the workers in hairdressers' salons Mondays as their weekly day off because the law made such a decision an individual matter and not a regulatory matter.

Collective interests may also justify actions by individuals. In Casanova, local taxpayers were able to bring an action to challenge the refusal by the prefect to annul the decision of their commune to pay for a municipal doctor to provide free medical care for poor people. ${ }^{11}$ The Conseil found that there was no need for this appointment, as two doctors already provided adequate care. In line with this case, the Conseil d'Etat eventually allowed local taxpayers to challenge not only decisions which increase local taxes, but also decisions which suspend taxes and diminish a city's income. ${ }^{12}$ The courts have not wished to allow people to bring actions where their interests are only secondary. They have insisted that claimants be affected in a sufficiently particular way. Illustrations of statuses which have not been held sufficient for standing include a national taxpayer challenging a government publicity campaign, ${ }^{13}$ a 'French citizen' concerned about state support for religion in Alsace-Lorraine, ${ }^{14}$ a consumer challenging a ban on a pharmaceutical product ${ }^{15}$ and a television viewer concerned for children and complaining about the lyrics of a broadcast pop video. ${ }^{16}$ The peculiar treatment

\footnotetext{
CE Sect. 18 January 2013, no. 354218, Leb. 5 .

CE 28 December 1906, no. 25521, S. 1907.3.23 concl. Romieu.

CE 29 March 1901, Casanova, no. 94580, S. 1901.3.73 note Hauriou.

CE 1 July 2009, Kohumoetini, no. 324206.

CE 23 November 1988, Dumont, no. 94282, Leb. 418.

CE 17 May 2002, Epoux Hofmann, no. 231290, Leb. 943.

CE 29 December 1995, Beucher, no. 139530, Leb. 480

CE 16 January 2002 Stiegler, no. 230386, Leb. 10.
} 
of local taxpayers is paralleled by art. L2132-5 CGCT, which allows the tribunal administratif to allow a local taxpayer to bring an action on behalf of the commune (at his own expense) when the commune itself has neglected to bring the action. The small size of many communes perhaps explains the concern that corruption may prevent challenges being brought by elected offcials, a concern that is not as prevalent at the national level.

\subsection{WHAT KINDS OF DECISIONS CAN BE CHALLENGED?}

The discussion of standing has already brought out that there is a distinction between individual decisions (actes individuels) and rules or regulatory decisions (actes réglementaires). On the whole, it is easier for associations to challenge regulatory decisions and for individuals to challenge individual decisions affecting them.

\subsubsection{The Need for a Prior Decision}

French law insists that there be a prior administrative decision to be challenged. This is a legacy of the nineteenth century, when the administrative courts only dealt with litigation and were not the general judges of the legality of administrative decisions. ${ }^{17}$ There can be no hypothetical actions and French law does not have the equivalent of a declaratory action, such as was used in the litigation prior to the withdrawal of the United Kingdom from the European Union. ${ }^{18}$

The rule requiring a prior decision (la règle de la decision préalable) allows a challenge to unilateral decisions - ones which are an exercise of authority. Such a decision must have legal consequences - either establishing a norm of conduct in the case of a regulatory decision or changing the legal situation of an individual in the case of an individual decision - for example, requiring them to pay money. The case law is quite flexible about the existence of a decision as shown by the 1986 Cusenier case. Mrs Cusenier challenged the decision of the Ministry of Culture to build the famous 'colonnes de Buren' in the front of both the Ministry of Culture and the Conseil d'Etat. The commissaire du government stated he had not found any formal decision, but that there must be a decision prior to a public expense. ${ }^{19}$ The requirement is now laid

See M. Guyomar and B. Sellier, Contentieux administratif, 5 th ed. (Paris: Dalloz, 2019) \& 646.

18 See R (on the Application of Miller) $v$ Secretary of State for Exiting the European Union [2017] UKSC 5 .

19 CE 12 March 1986, Ministre de la culture c Mme Cusenier, no. 76147, Leb. 661. The picture on the cover of this book shows the colonnes de Buren. The Ministry of Culture is in the foreground to the left, and the Conseil d'Etat lies at the back. 
down in art. R421-1 CJA, and since 2014, there is no exception for public works. That provision lays down that a challenge seeking the payment of money must be preceded by a request for payment. The existence of such a decision is established at the date that the claim is made to the court. Where the administration has simply failed to respond to a complaint, then its silence for two months used to be treated as a rejection. Since 2014 for state bodies and 2015 for local government, art. L231-1 CRPA lays down that the silence of the administration after two months constitutes acceptance. Numerous exceptions are made to this, and so a list of those decisions to which this rule applies is kept on the government website. Although this list does not have legal status as such, the claimant can always rely on the general principle in the absence of a specific exception. ${ }^{20}$

\subsubsection{Circulars and Soft Law}

In terms of general measures, some such as decrees and by-laws clearly have legal effect. But it has taken French law longer to recognise the legal effect of soft law measures such as circulars (circulaires) and guidelines (directives) and various 'grey literature' through which the wishes and understandings of higher organs of the administration are communicated to lower officials and to the public.

\subsubsection{Circulars}

Circulars are internal measures by which ministers advise officials how to apply the law. Typically, these are more detailed and try to ensure discretion is exercised more uniformly. In practical terms, these may become the documents of reference for officials, rather than the parent laws and decrees. There is a distinction between circulars that simply provide information and those that provide new instructions. In the past, a distinction used to be made between circulars that interpreted existing rules and those creating new rules, but that really failed to grasp the creative power of new 'interpretations' of existing rules. The Conseil adapted its approach in Duvignères by adding another possible situation. ${ }^{21}$ In this case, the claimant challenged both a decree of 1991 and a circular of 1997 governing legal aid in that neither excluded a personal housing allowance benefit from the calculation of resources determining the eligibility to legal aid. The law on legal aid of

20 See Chapter 4, note 32.

${ }^{21}$ CE Sect. 18 December 2002, Mme Duvignères, no. 233618 , Leb. 463 concl. Fombeur. 
1988 had excluded family housing allowance from such a calculation, but left it to the administration to determine what other social welfare benefits to exclude. The different treatment of the two types of housing allowance breached the principle of equality, and so the provision in the decree was annulled. As regards the circular, the Conseil distinguished between circulars interpreting laws and decrees and imperative circulars with general application. The latter would be subject to review. But as long as they did not contain imperative elements, the former would not. A circular would be imperative if either it imposed a rule where the legislation was silent or it misapplied the legislative provision which it purported to explain or it repeated a legislative rule which was, in itself, unlawful. This last was the case of the 1997 circular. But importantly, there is a distinction drawn between the faithful interpretation of a decree and a misguided one. Legality is the central feature which determines whether the circular can be challenged. Those which are imperative can always be challenged, but those that are not imperative in the ways described cannot. All the same, inadequate interpretation can be sufficient to cause provisions in a circular to be annulled. For example, the Conseil d'Etat annulled paragraphs of the official commentary on the tax code which failed to mention clearly the interpretation given by the Conseil constitutionnel to provisions on dividends. ${ }^{22}$ Since the 2020 GISTI case (see Section 6.2.2.3), case law has evolved to adopt a common approach to what is usually called in French 'soft law' or droit souple, including circulars and guidelines.

\subsubsection{Guidelines}

Guidelines (formerly called directives and now lignes directrices in French so as not to be confused with European directives) are further examples of 'soft law'.23 They guide the conduct of officials and ensure uniformity, but obviously this affects those dealing with the administration in that the guidelines will be typically applied to them. So there is no objection in principle to the administration producing guidelines where the legal texts do not set out all the conditions necessary for their application, but they cannot add new rules. Unlike legal rules, the administration is at liberty to depart from the guidelines in individual cases. Indeed, it is necessary for the administration to consider both the requirements of the public interest and the totality of the facts of the individual case before applying

22 CE 8 June 2016, Association française des entreprises privées, no. 383259, Leb. 230.

23 Following the Rapport Public of 2013 on Le droit souple. This usage is borrowed from EU law: see, for example, Case 17/99, France v Commission [2001] ECR I-2481. 
the guidelines. ${ }^{24}$ Accordingly, in Cortes Ortiz, an applicant for a residence permit could not rely on the guidance alone to complain that the prefect had refused him a permit on a full examination of his particular case. ${ }^{25}$

\subsubsection{Other Soft Law and Information}

Such guidance is often produced by regulatory bodies. They may also issue other forms of soft law: 'advice', 'recommendation', 'position statements' or 'warnings' which may have an effect on individuals. In Fairvesta, the financial markets authority (Autorité des marchés financiers) issued a 'warning' notice about the activities of the claimant and its products retailed in France as a result of complaints by investors. ${ }^{26}$ The claimant company sought judicial review to quash the warnings and sought compensation for losses incurred. The Conseil accepted that this was the kind of administrative action which could be challenged in this way. In line with the case law we have just seen on guidelines, it held that general and imperative soft law provisions or individualised provisions which could later be used to sanction non-compliance could be challenged. In addition, challenges could be made to measures which are capable of having a significant economic or other effect, or are designed to influence the behaviour of those to whom they are addressed. In this case, there had been a significant drop in investments in the financial products of the claimant, and this justified permitting a legal challenge to the legality of the measure. But, on the merits, the claim failed since no manifest error in assessment was shown.

For a general measure to be reviewable, it must traditionally have a normative effect. ${ }^{27}$ The Conseil d'Etat clarified this in relation to what the French call 'grey literature' (la literature grise):

Documents of a general character put out by public authorities, whether in physical form or not, such as circulars, instructions, recommendations, notes, presentations or interpretations of positive law may be submitted for judicial review when they are capable of having significant effects on the rights or situations of people other than the officials charged with implementing them in a relevant case.

26 CE Ass. 21 March 2016, Société Fairvesta International GmbH, no. 368082, Leb. 77; AJDA 2016, 717; also Société NC Numéricable, no. 390023, Leb. 89. Once a recommendation is made, it must be kept up to date in the light of scientific advances: see CE 23 December 2020, Association Autisme Espoirs vers l'Ecole, no. 428284, AJDA 2021, 11 and 948.

27 CE Ass. 29 January 1954, Institution Notre-Dame du Kreisker, no. 07134, Leb. 54. 
The phrase 'significant effects' (effets notables) is more wide-ranging than simply requiring that the measure be of normative effect. In the case in hand brought by GISTI, the information update (note d'actualité) drew the attention of officials to possibly fraudulent documentation coming out of Guinea (Conakry). ${ }^{28}$ It did not require officials to act in a particular generalised way. Since it encouraged attention to potential fraud on a case-by-case basis, then the document in question was not reviewable. All the same, this is a significant advance in ensuring legal certainty.

\subsubsection{Internal Measures}

Many circulars and guidance notes are for the internal use of members of the public service, and that is why the control exercised by the courts was originally very limited. Judicial review was intended to protect citizens from the administration. Internal matters would usually have their own schemes of redress - for example, in public service employment or in the military - or would be of minor significance - for example, the opening hours of post offices. Measures of internal organisations of the public service (mesures d'ordre intérieur administratives) are generally not subject to judicial review, whereas in the past, public service organisations such as the army, prisons and schools were considered closed institutions where internal discipline should not be weakened. This has become untenable, at least where individual rights are affected. The leading decisions are now Hardouin and Marie. ${ }^{29}$ In Hardouin, a sailor was found drunk on shore leave in the Canaries and he refused to take a breathalyser test. He was punished by ten days in jail. In Marie, a prisoner complained he was being refused dental treatment and was punished by the governor with eight days in a punishment cell. The lower courts rejected their claims against these decisions on the ground that such decisions were internal measures, applying the then consistent case law of the administrative courts. But the Conseil d'Etat overruled that case law and declared the claims to quash the decisions admissible. In Hardouin, the Conseil noted that the punishment had direct effects on the freedom of movement of military personnel outside their hours of duty and also on promotion and the renewal of their contracts of service. For these reasons, the sailor was allowed to challenge the decision. His various grounds of appeal were, however, rejected. By contrast, in Marie, the claimant was able to show

CE Ass. 17 February 1995, Hardouin and Marie, nos. 107766 and 97754, Leb. 82 and 85 concl. Frydman; AJDA 1995, 379. 
successfully that his punishment was not justified. His letter complaining of the medical services in the prison might have been intemperate, but it was not outrageous, threatening or insulting. The seriousness of the penalty imposed justified him being given the right to bring a complaint and the lack of factual basis for the governor's decision justified the quashing of his decision. To encourage the Conseil to reverse its case law, the commissaire du gouvernement relied on the European Convention on Human Rights and the development of case law on such matters in countries comparable to France. The principles laid down in this decision are that the courts will entertain complaints which either affect fundamental rights or which have serious consequences. For example, where legislation permitted prisoners to use their own computers, the refusal to allow a prisoner to acquire a particular operating system for computer was not significant enough to be reviewable. But the seizure of his equipment did constitute a measure interfering significantly with his right. ${ }^{30}$

The availability of judicial review in relation to school discipline was recognised earlier. In Chapou in 1954, the Conseil d'Etat refused to quash a Paris school headmistress's rule that girls were forbidden to wear ski trousers as a purely internal matter of discipline. ${ }^{31}$ But in Kherouaa in 1992, parents of pupils were allowed to challenge the exclusion by the headmaster of female pupils who wore a Muslim headscarf within the school. $3^{2}$ At the time, this was a highly controversial topic and in 1989 the Conseil d'Etat had issued advice to the Minister of Education that pupils had a right to freedom of conscience and were entitled to express their religious beliefs, provided this was not done in an ostentatious or provocative manner. That advice was put into a ministerial circular to schools and was followed by the Conseil d'Etat in this case. This school's ban on wearing a headscarf was too broad. It was general and absolute, rather than an appropriate response to particular identified problems with how the girls were behaving, and did not show proper consideration of the right of the pupils to freedom of conscience and expression. Again, the concern for fundamental rights, especially those recognised in the European Convention, influenced a change of approach by the Conseil d'Etat and justified allowing challenges to internal rules of the public service. Eventually the legislator banned in 2004 any ostensible religious signs in state schools, allowing only discreet ones.

\footnotetext{
CE 9 November 2015, D and B, nos. 380982 and 383712, AJDA 2016, 53.

CE 20 October 1954, Chapou, no. 15282, Leb. 541.

2 CE 2 November 1992, Kherouaa, no. 130394, AJDA 1992, 788.
} 


\subsubsection{Actes de gouvernement}

The immunity of the state attaches to sovereign acts (actes de gouvernement) what English lawyers refer to as 'acts of state'. To begin with, this was a wide category. In 1875 in Prince Napoleon, the cousin of the former Emperor Napoleon III was omitted from the annual army list of 1873 by the Minister of War as a result of the change of regime in 1870 . The Conseil d'Etat refused his claim to annul the decision. But the decision already marked a step towards a modern understanding of the rule of law in that it implicitly rejected the idea that all politically motivated decisions were not susceptible to judicial review. At that time, a wide range of discretionary decisions taken by ministers or by the head of state were considered to fall within the category of actes de gouvernement. But the list has reduced over the years. Prerogatives of the head of state, such as declarations of amnesty or pardon, ${ }^{33}$ decisions to extradite foreigners ${ }^{34}$ or decisions of the Prime Minister to nominate a member of Parliament for a mission ${ }^{35}$ are not included. Following the view of the European Court of Human Rights, the courts no longer defer to the interpretation of the Ministry of Foreign Affairs when interpreting a treaty. ${ }^{36}$ There are, however, a small number of topics on which the administrative courts will not permit claims to be brought because they are actes de gouvernement. Decisions in relation to the legislative process and the relationships between government and Parliament are not amenable to review, such as whether to submit a draft bill for consideration by Parliament or whether to refer a matter to the Conseil constitutionnel. The use of constitutional powers is similarly not amenable - for example, the use of art. 16 of the Constitution to declare a state of emergency or the use of art. 11 to submit a legislative proposal to a referendum. Both of these were controversial at the beginning of the Fifth Republic. The decision to invoke art. 16 is subject to prior advice of the Conseil constitutionnel, even if that advice does not have to be followed, and so in Rubin de Servens no challenge could be brought to the use of this procedure after the attempted military coup in Algeria in 1961 to establish special courts which punished the officers involved, ${ }^{37}$ nor could the use of a referendum to change the Constitution and establish the direct election of the President. $3^{8}$ Similarly the dissolution of the National

33 CE 30 June 2003, Section française de l'observation internationale des prisons, no. 244965 , Leb. 296.

34 CE Ass. 30 May 1952, Dame Kirkwood, Leb. 291.

35 CE Sect. 25 September 1998, Mégret, no. 195499.

36 CE Ass. 29 June 1990, GISTI, no. 78519, AJDA 1990, 621 concl. Abraham.

37 CE Ass. 2 March 1962, Rubin de Servens, no. 55049, Leb. 143.

$3^{8}$ CE Ass. 19 October 1962, Brocas, no. 58502 , Leb. 553. 
Assembly is not reviewable. ${ }^{39}$ In the Fifth Republic, referendums and parliamentary elections are scrutinised by the Conseil constitutionnel (and it has an abundant caseload after each election). So these matters fall outside the competence of the Conseil d'Etat, which deals merely with local elections. On the other hand, implementing decisions will be subject to review. For example, the decision of the Conseil Economique Social et Environnemental to reject a reference made to it was capable of review. ${ }^{\circ}$

Government actions in relation to defence and foreign affairs are also not susceptible to review. Thus, in 1995, the President decided to resume the testing of nuclear weapons in French Polynesia. A challenge brought by Greenpeace was unsuccessful because the President's decision could not be separated from the conduct of international relations. ${ }^{41}$ The doctrine was successfully invoked to shelter from review a ministerial circular cancelling the registrations of Iraqi students at French universities after the outbreak of the First Gulf War. ${ }^{42}$ Similarly, the failure of the French government to do enough to repatriate its citizens from the civil war in Syria could not be challenged. ${ }^{43}$ The use of powers in relation to a treaty are not subject to review. For example, the vote by a French minister in the Council of the European Union (as it is now called) could not be reviewed, ${ }^{44}$ nor could the decision to suspend the implementation of a treaty. ${ }^{45}$

Two limits apply in any case to the unreviewable character of actes de gouvernement. First, under art. 55 of the Constitution, treaties that have been duly ratified have a higher status than laws, decrees and regulations in French domestic law. As a result, a litigant can challenge a decision that is contrary to a ratified treaty. ${ }^{46}$ Second, the exclusion of foreign affairs only applies to sovereign acts. Many decisions, such as signing a treaty, are distinct from sovereign acts, and these separable decisions (actes détachables) are subject to review. For example, the decision to negotiate and sign an extradition treaty is a sovereign act. But the decision to make use of a power in such a treaty to request the extradition of an individual is a separable decision and is thus subject to

39 CE 20 February 1989, Allain, no. 98538 , Leb. 20.

$4 \circ \mathrm{CE} 15$ December 2017, Brillault, no. 402259, AJDA 2018, 491.

$4^{1}$ CE 29 September 1995, Association Greenpeace France, no. 171277, Leb. 348. See also CE 30 December 2003, Comité contre la Guerre en Iraq, no. 255904, Leb. 707.

$4^{2}$ CE 23 September 1992, GISTI and MRAP, no. 120437, AJDA 1992, 752 concl. Kessler.

43 CE ord. 23 April 2019, Mme C and Mme D, no. 429668, AJDA 2019, 907.

44 CE Ass. 23 November 1984, Association 'Les Verts', no. 54359, Leb. 382.

45 CE Ass. 18 December 1992, Préfet de la Gironde c Mahmedi, no. 120461, RFDA 1993, 333 concl. Lamy.

46 CE Ass. 20 October 1989, Nicolo, no. 108243, AJDA 1989, 756 and 788. 
review. ${ }^{47}$ Indeed, the Conseil d'Etat has accepted that it can review the refusal to extradite an individual at the request of a foreign government. In Colonie Royale de Hong Kong, the French government rejected a request by the United Kingdom and the Governor of Hong Kong (then a British colony) to extradite a Malaysian businessman, Sanimam, to Hong Kong on charges of fraud and corruption. ${ }^{4}$ The Conseil accepted the claim by the United Kingdom and the Governor of Hong Kong to quash the refusal on the ground that the French Minister of Justice had committed errors of law in coming to his decision, which was contrary to the favourable advice given by the chambre d'accusation of Versailles. ${ }^{49}$

As the authors of the Grands Arrêts suggest, there is no longer a general theory of actes de gouvernement. Rather, there is a natural reluctance of the judicial branch to interfere with the special prerogatives of the legislative and executive branches, including the diplomatic function. ${ }^{50}$

\subsection{IS JUDICIAL REVIEW INAPPROPRIATE?}

Because of the availability of other routes to redress, judicial review may be inappropriate either for the administration or for a particular litigant. The courts do not wish to receive unnecessary litigation. In the case of the administration, it may well already have powers to deal with a situation. After all, the privilège du préalable (the right to act first and be questioned later) gives the administration a strong position. For example, a département had the power on its own authority to withdraw a subsidy for a health centre in a local commune. Accordingly, it did not need to obtain a court order that it had lapsed. ${ }^{51}$ Similarly, a municipal authority was entitled to issue an order to pay to the co-owners of property which the authority had repaired because of its dangerous state. The lower court was wrong to insist that it wait until a court order to pay had been issued. ${ }^{52}$ The case law went even further by dismissing an action in court if it has power to act itself.53 There is only one exception for public contracts, as will be seen in Chapter 9, Section 3.2.

47 CE Sect. 21 July 1972, Legros, no. 82147, Leb. 554 (but in that case only subject to challenge in the extradition proceedings in the criminal court).

$4^{8}$ CE Ass. 15 October 1993, Royaume-Uni et Gouverneur de la Colonie Royale de Hong Kong, no. 142578 , Leb. 267 concl. Vigouroux.

49 The French government then ordered the extradition of Sanimam and the Conseil d'Etat rejected his challenge to this decision: CE 29 July 1994, Sanimam, no. 156288, Leb. 368.

$5^{\circ}$ P. Delvolvé, M. Long, P. Weil, G. Braibant and B. Genevois, Les Grands Arrêts de la Jurisprudence Administratif, 22nd ed. (Paris: Dalloz, 2019), p. 28.

51 CE 21 July 1989, Commune de Noisy-le-Grand, no. 88120, Leb. 866.

52 CE 18 May 1988, Ville de Toulouse, no. 39348, Leb. 939.

53 CE 9 May 1913, Préfet de l'Eure, no. 47115, Leb. 583. 
In the case of a private individual, there may be an alternative remedy that he or she should pursue before seeking judicial review of an administrative decision. For example, if a company considers it has paid too much value-added tax (VAT) because France was slow in implementing an EU Directive, it must challenge this by way of the normal appeal on tax matters and not pay - one of the rare remedies having a suspensive effect ${ }^{54}$ - and then seek to obtain an 'indemnity' for the wrong done to it by the illegal request for tax. ${ }^{55}$ Similarly, those who have a priority right to housing should make use of the special procedure to enforce this right under the Housing Code, rather than seeking a judicial order in judicial review proceedings under the general CJA.$^{56}$ Where special procedures have been designed by the legislator, judicial review cannot be used to evade their procedural and other requirements and safeguards.

\subsection{TIME LIMITS}

As in many countries, the need for certainty has led French administrative law to insist on short limitation periods for bringing proceedings against the administration. If a challenge is brought a long time after an administrative decision is made, this may upset both the effective implementation of policies and the interests of other citizens. The basic principle is that the litigant has two months in which to challenge an administrative decision. Special rules apply to particular decisions. For example, a member of the public potentially affected can challenge permission to make use of works for the protection of the environment up to four months after notice of the permission was posted on the building (and thus when she might reasonably learn about it). ${ }^{57}$ On the other hand, some time limits are very short. For example, a candidate wishing to contest the results of a local election has only five days in which to present a claim..$^{8}$

In order to make it reasonably possible to bring a claim, the time limit runs from the date a decision was made public, rather than from the day on which it was made. Some decisions, such as planning permissions, have to be presented in a certain manner so that the attention of interested parties is drawn to their essential content. Article R421-5 CJA requires the administration to inform the affected person of the time limit for action and competent court when informing

54 However, this suspensive effect is not permitted in case of illegal state aid as contrary to the principle of effectiveness of EU law: see ECJ 5 October 2006, Case C-232/05, Commission v France ECLI:EU:C:2006:651 (aid granted to Scott Paper SA/Kimberly Clarke).

55 CE Ass. 30 October 1996, SA Dangeville, no. 141043, Leb. 399.

56 CE 3 May 2016, Lourdjane, no. 394508, Leb. 155.

57 Art. R514-3-1 Code de l'environnement.

$5^{8}$ Art. Riıg Code électoral. 
her of an individual decision to the interested person. If it fails to do so, the time limit does not run. But the Conseil d'Etat set out a time limit for the reason of legal certainty: if it is established that the affected person was aware of the decision, she must act within a reasonable time, which is 'in principle' one year after the decision was taken, unless particular circumstances justify another time limit. ${ }^{59}$ In that case, Czabaj, a retired policeman, challenged the decision that set his pension twenty-two years after this decision on the ground that the decision had failed to mention the competent court. The Conseil d'Etat dismissed his claim on the ground that there were no special circumstances to allow the action.

\subsection{CAN JUDICIAL REVIEW BE EXCLUDED?}

In the past, there have been debates in France and among foreign commentators about whether the right to challenge an administrative decision could be excluded by the legislator. The current position is neatly summarised by the editors of Grands Arrêts: ${ }^{60}$

Under the double influence of the increasing place of international agreements in domestic law and the expansion of constitutional review of laws exercised by the Conseil constitutionnel, it seems possible to assert that a legislative provision which sought to remove an administrative decision from all judicial control would clash both with the international norm as well as with the constitutional norm.

That remark is made as a comment to a decision of 1950, Dame Lamotte, in which a Vichy Law of 1943 provided that the decision to award a unilateral concession, a sort of licence, could not be challenged by any administrative or judicial means. ${ }^{61}$ All the same, the Conseil d'Etat allowed a challenge by a landowner against a decision to grant a concession over her land to another person for nine years on the ground that it had been uncultivated for two years. It ruled that the law 'had not excluded judicial review before the Conseil d'Etat against the concession decision, a review which is available even without any (specific) provision against any administrative decision and which has the effect of ensuring respect for legality in conformity with the general principles of law'. This 'general principle of law' was converted into a 'principle of constitutional value' by the Conseil constitutionnel in $1994 .{ }^{62}$ The Conseil constitutionnel will

59 CE Ass. 13 July 2016, Czabaj, no. $3^{87763}$, Leb. 340.

6o Delvolvé et al., Grands Arrêts, p. 368.

61 CE Ass. 17 February 1950, Minister of Agriculture c Lamotte, no. 86949, Leb. 110. See Chapter 4 , note 4 .

62 CC decision no. 93-335 DC of 21 January 1994, Rec. 40. 
strike down not only a total exclusion, but also an effective exclusion. For example, where a law provided that a foreign national held in detention could only challenge an order for his expulsion from France within five days, the Conseil struck down the provision as breaching his right to a legal remedy. ${ }^{6}$ The principle of a right to recourse to the courts is recognised as a general principle recognised by the constitutional traditions of the Member States of the EU. ${ }^{64}$ It is also recognised by art. 47 of the European Charter of Fundamental Rights and art. 13 of the European Convention on Human Rights.

\subsection{REMEDIES}

The French administrative law on remedies is simpler than the array of orders in English law which still bear the marks of their origins in the prerogative writs and the remedies of Chancery. In France, there are basically orders to nullify or quash a decision or orders to require a person to act or to refrain from acting. In Chapter 4, Section 3, it was explained that interim remedies can be requested as a matter of urgency. In that chapter, the illustrations, particularly the handling of Covid-19 cases, showed how the interim procedure, particularly the référé-libertés, can effectively be the disposal of a specific problem. The problem of whether churches would be open for public worship during the pandemic would have disappeared if the normal process and time period were followed before the courts came to a decision. ${ }^{6}$ The range of remedies is available in interim cases as well as in final cases.

\subsubsection{Nullity}

In relation to the illegality of an administrative decision, a common remedy is nullity, which in England is known as a quashing order. Nullity declares that the administrative decision never took place, and it brings the situation back to where it was before the decision was taken.

\subsubsection{What Is the Effect of Nullity?}

Putting things back to where they were is not always easy or desirable. It is not always easy because time has elapsed since the original decision was made. In the case of a public employee, the lapse of time may mean a loss of opportunity

63 CC decision no. 2018-709 QPC of 1 June 2018, AJDA 2018, 1131.

64 Case 22/84, Johnston v Chief Constable of Northern Ireland [1984] ECR I-1651.

65 See Chapter 4 , note 53 , and text thereto. 
for experience or promotion. For a century, the French administrative courts have linked the nullity of promotions or lists of promotions with the power to reconstitute the careers of those affected in the light of typical patterns of advancement. In Rodière, the claimant had successfully brought an action to quash the list of promotions which the Minister for the Liberated Regions had drawn up for 1921 in which a number of individuals appeared. ${ }^{66}$ In 1925, the Minister then regraded them back to the grade they occupied in 1921 and then gave them the typical promotion they would have had in the intervening period. The claimant was unsuccessful in challenging this as a misuse of power. The effect of a nullity should not be to set everything back to the beginning and make the civil servants start again to earn their promotion. Rather, the individuals should have the guarantee of the continuity of career which they expected at the time of the original unlawful decision.

As noted in Chapter 4, the Conseil d'Etat has accepted in this century to permit the practice of prospective nullity as a way of safeguarding legal certainty. The decision in Association AC! demonstrates the value of a prospective nullity of legal rules which thereby protects the acquired rights of those appointed under them. ${ }^{67}$ The alternative for a court is to grant a suspensive effect to a nullity which allows an orderly transition back to legality. For example, in the Church Gatherings case discussed in Chapter 4, Section 3, provisions in the Prime Minister's Covid-19 decree were quashed, but the effect was suspended for a week to enable the Prime Minister to make a new decree to regulate the situation. This permitted there to be some rules in place during the interim to deal with the serious health crisis in question.

\subsubsection{Can Nullity Be Avoided?}

The courts have adopted four techniques to avoid declaring an administrative decision null whilst restoring a lawful situation. These are interpretation, substituting a proper legal basis to the decision, correction and declaring an error not to be substantial.

Interpretation constrains the meaning of a provision and "extracting its venom'. For example, in Sueur, the loi d'habilitation had given power to make an ordonnance in order to introduce PPP contracts, but had required the government to ensure fair access to small and medium-sized enterprises in

CE Ass. 11 May 2005, Association AC! and Others, no. 255886, Leb. 917 concl Devys; Chapter 4, Section 9. 
the award of component parts of contracts. ${ }^{68}$ The Conseil d'Etat refused to nullify the ordonnance because it did not require small and medium-sized enterprises to be included in all public contracts awarded. But it did interpret the provisions in question so as to maintain the powers of a public authority to intervene if the potential participation of small and medium-sized enterprises was being neglected, and so as to maintain the effect of specific rules which guaranteed payment within a reasonable period to subcontractors. This avoided the danger that small and medium-sized enterprises would be excluded without declaring null rules that had been applied in relation to many public contracts.

Substituting a legal basis for an administrative decision enables the court to find a valid legal basis, even if it was not the one cited in the challenged decision. In Préfet Seine-maritime c El Bahi, the Conseil d'Etat declared: ${ }^{69}$

When it ascertains that the decision challenged before it could have been taken by a similar exercise of discretion on the basis of a legal text different from the one whose breach is alleged, the court in judicial review may substitute this legal basis for the one which served as the basis for the challenged decision, provided that the person affected has had available the safeguards relating to the application of the text on the basis of which the decision ought to have been made.

In this case, the prefect expelled a Moroccan from France on the basis of art. 22 (1) of the ordonnance of 1945 relating to foreign residents. However, he was able to show that he did not enter France unlawfully because he had a valid Italian residence card and was validly exercising free movement within the EU. But the Conseil d'Etat found that he had breached art. 22 (2) in that he had not obtained a French residence card within three months of his entry into France. By substituting this legal basis for the one mentioned in the prefect's order of expulsion, the prefect's decision was upheld. The court is allowed to come to this substitution decision in the light of all the evidence on file, as long as the parties have been given an opportunity to make observations on these issues. Indeed, a lower court commits an error of law if it fails to proceed on its own motion to make such a substitution of legal basis. In Nassiri, claimant children sought to change their surname from that of their father, who had abandoned them and taken no further interest in them, to that of their mother. ${ }^{70}$ The lower court simply reviewed the Minister's refusal to see whether there had been a manifest error in evaluation. But the Conseil

68 CE 29 October 2004, no. 269814, AJDA 2004, 2383.

69 CE Sect 3 December 2003, no. 240267, Leb. 479 concl. Stahl.

70 CE 31 January 2014, Ministre de l'Intérieur c Nassiri, no. 362444 , Leb. 698. 
d'Etat substituted a normal control assessment and concluded that the Minister had failed to take account of the legitimate interest the children had on these exceptional facts to be rid of any association with their father. Obviously, such a correction of legal basis may simply involve selecting among the reasons offered by the administration and disregarding those which are illegal. But that only works if the court is sure the official would have taken the same decision on the basis of the other facts mentioned in its reasons for the decision. $^{71}$

The court may refuse to annul a decision on the ground that the illegality found in the decision was not substantial. For example, a decision declaring a project of public utility was not quashed where errors in the notice of a public inquiry did not appear to have prevented a significant number of people making representations to it, and errors in required information did not significantly alter the scale of the cost. ${ }^{72}$ Here the court is avoiding requiring the administration to take back a decision and remake it with the same result. Consistent with but going beyond this case law, the Conseil d'Etat now asserts that

If administrative acts must be taken in accordance with the forms and procedures provided for by the laws and regulations, a defect affecting the conduct of a prior administrative procedure, whether compulsory or optional, may render the decision taken unlawful only if it is clear from the documents on file that it was likely to influence the meaning of the decision taken in the case in question or that it deprived the persons concerned of a guarantee. ${ }^{73}$

\subsubsection{Injunctions (Injonctions)}

In Chapter 4, Section 9, it was noted that there was a long reluctance to allow the courts to issue injunctions against the administration. But this was permitted by legislation in 1995 (now enshrined in arts. L911-1 and L911-2 CJA), and it has become commonplace. Article L911-1 allows the court, when requiring a decision to be made with particular content, to require that the decision is made within a specified time. Article L911-2 provides that where the public

${ }^{11}$ CE Ass. 12 January 1968, Ministre de l'Economie et des Finances c Perrot, no. 70951, AJDA 1968, 179 concl. Kahn. (In that case, the Conseil d'Etat was not convinced the same decision would have been made.)

$7^{2}$ CE 3 July 1998, Association de défense et de protection de l'environnement de Saint-Come-d'Olt, no. 162464 , Leb. 283 .

73 CE Ass. 23 December 2011, Danthony, no. 335033, Leb. 649. 
body has to remake a decision in the light of a review of the facts, then it can be required to act within a specified time. This power was used effectively in the cases relating to gatherings in places of worship during the Covid-19 crisis. In two decisions, the Conseil d'Etat in référé-liberté decisions annulled the provisions relating to the numbers permitted to gather for worship in churches and ordered the Prime Minister to produce new rules within a week. ${ }^{74}$

Injunctions may thus not only be to refrain from acting, but also may require action. In this way, they cover what are described in English law as mandatory orders, prohibiting orders and injunctions. For example, it may accompany the nullity of planning permission with an injunction requiring the landowner to demolish a car park being constructed on the basis of that planning permission. ${ }^{75}$ It may also be used in conjunction with a référé suspension. In that case, the order can also require actions but only as long as they are reversible. For instance, the suspension of a university decision refusing a student progression to a superior academic year is possible only if this admission is temporary - that is, valid until the court takes a position on the substance of the claim.

French law does not have a procedural equivalent to the English contempt of court in order to enforce such injunctions. Instead, it uses the procedure of astreinte discussed in Chapter 4, Section 8. This financial penalty is set at a level to encourage action. It is either a lump sum or a penalty fixed for a short period - for example, an amount per week. This idea of a financial penalty awarded against the administration has found its way since 1993 into EU law, where it features among the sanctions the CJEU can apply under art. 260 TFEU.

\subsubsection{Declaratory Judgments}

French administrative law does not have a category of 'declaratory judgments'. There is no real place for the equivalent of the procedure which exists in English law. In the first place, as has already been seen, there must be a prior administrative decision. There is no place for an action brought in anticipation of an administrative decision as was done in $R$ (on the Application of Miller) $v$ Secretary of State for Exiting the European Union. ${ }^{76}$ At the very least, there must be a circular which has an impact on individual situations. Second, French courts do not deal with hypothetical cases, but concrete situations. On

\footnotetext{
4 See Church Gatherings, Chapter 4, and Association Civitas, Chapter 7.

5 See CE Sect. 14 October 2011, Commune de Valmeinier, no. 320371, AJDA 2011, 2226.

$7^{6}$ See note 18.
} 
the whole, the French administration is allowed to act and, if it acts unlawfully, it pays.

That said, there are a few instances of judgments which have a declaratory effect. The first is when a court is invited to clarify its previous decision. This will often be a request by the administration to make more explicit the consequences of a previous court ruling. Clearly, there is no new decision here, as there would be in an appeal, so the new decision is merely declaratory in nature.

\subsubsection{Correcting a Decision}

Where an administrative decision comes to the court by way of appeal, the court is able not just to quash the decision, but also to correct it. In principle, such a power can be exercised in the plein contentieux rather than in the recours pour excès de pouvoir, though some of the techniques noted for avoiding the nullity of a decision may have a similar effect. Correction will often happen in tax matters. Where the claimant establishes an error in the basis on which he has been taxed, then the court may be in a position, on the basis of the facts on file, to come up with the correct amount of tax the claimant owes. For example, where the tax authorities applied an inappropriate rule to calculate the value of an option the taxpayer had exercised so as to treat it as the transfer of a business, the Conseil d'Etat simply reassessed the tax due on a basis which excluded the wrongly applied rule and treated it merely as a transfer of empty property. ${ }^{77}$

Similarly, election litigation may lead the court to alter the results. For example, in relation to local elections in French Guyana, the ballots in one commune had been wrongly rejected. The court simply recalculated the results including these ballots. ${ }^{8}$

\subsection{COSTS}

Orders in relation to costs have to distinguish between the costs incurred by the court (les dépens) and those incurred by the parties (les frais liés à l'instance). Under art. R761-1 CJA, the administrative court can make a ruling of its own motion in relation to court costs (les dépens), which will include the costs of court experts, of any investigation or of other measures ordered by the court to inquire into the facts of the case. The only exception

77 CE 28 December 2002, Société Valeo équipements électriques, no. 362444, Leb. 844.

$7^{8}$ CE 20 February 2020, Elections municipales Saint-Elie, no. 235473, Leb. 755. 
are expenses which are part of the running costs of the court, including the cost of site visits. That article provides that normally the court costs are to be borne by the losing party, but the court may order them to be borne by the state. It is up to the parties to make submissions that their costs should be met by the other side. Their own costs will typically be the costs of their avocat, the cost of the huissier who has produced a formal record of the state of premises at a key moment and any other costs the party has incurred in conducting the litigation. These frais will be borne by the party on whom the court costs are imposed or, by default, on the party who loses the case. The judge exercises a discretionary power with regard to these party costs. In the light of the justice of the case and the economic situation of the party in question, the court may order all or part of the costs to be borne by the losing party but with no correlation to the actual costs. (Typical amounts are from $€_{1,000}$ to $€_{5}, 000$.) Where the losing party has been allowed legal aid, the state will bear the party costs awarded against the losing party. Although the court has a discretion, it cannot award party costs against the winning party. Where a public body has not employed an external lawyer, but has conducted the litigation through its in-house staff, it may only recover any additional costs it can identify that are attributable to this specific litigation. It may not claim a proportion of the general costs of running the in-house service which deals with litigation. ${ }^{79}$

\subsection{PENALTIES}

Under art. R741-12 CJA, the administrative court is empowered to fine a claimant for making an abusive claim. This is a power which belongs to the court and cannot be requested by the other party. The level of the fine is for the court to determine, but it is rare that the maximum (at the time of writing) of $€_{10, \infty}$ is imposed. ${ }^{80}$ This fine may be the subject of appeal. The imposition of this fine does not prevent the other party to the case bringing a distinct claim for abusive proceedings. Before the administrative courts, the party wishing to make a claim that the other party's claim is abusive can only do so by way of counterclaim in pleine juridiction proceedings. It is not possible within judicial review proceedings. Exceptionally, planning law provides that, where a claim challenging planning permission also seeks the demolition of

$79 \mathrm{CE}_{3}$ October 2012, Ministre de la Défense et des Anciens combattants, no. 357248, AJDA 2012, 2178 concl. Dacosta.

8० For a rare case of a maximum penalty, see CE 10 July 2006, Jacques A, no. 294971. Here a judge dismissed after a disciplinary decision of the Conseil supérieur de la magistrature sought to challenge his dismissal on the (spurious) ground that such an administrative decision breached the principle of the independence of the judiciary. 
what has been constructed by the beneficiary of the planning permission, that party may be able to ask the court to award damages from the claimant for abusive proceedings (art. L6oo-7 Planning Code).

Article $741-2$ CJA provides that a court may order a litigant to suppress any insulting or defamatory remarks contained in his pleadings or in any report of the proceeding. This replicates powers that exist in private law in the press law of 1881 . In a sense, this is merely a power to curb the effects of an abuse of process, which in English law would be contempt of court.

\subsection{CONCLUSION}

France has distinctive administrative law procedures that have developed within its distinctive institutions. The distinction between public and private law has enabled procedures and remedies to be adapted to the context of relations between the administration and those it administers. That said, a number of procedures have been borrowed from private law. For example, administrative law adopted the astreinte after it had been successful in private law, and the injonction was another borrowing. It is notable that recent reforms, such as the Law of 23 March 2019 simplifying civil and administrative court procedure, view both branches of law together.

The distinctiveness of administrative law procedure has worked in two ways. On the one hand, especially in the early years, it has protected the administration. The requirement of an actual administrative decision that was either individual or normative restricted the range of administrative actions that could be challenged. In particular, it limited challenge to the range of soft law instruments which the administration uses to guide low-level decision makers and which are publicised to potential users of administrative services. There was no opportunity to challenge instructions before they were implemented. ${ }^{81}$ It protected the administration against hypothetical claims, but allowed it to act first and be challenged later (the so-called privilège $d u$ préalable). The administration was protected for a long time against hard-edged remedies such as injunctions. The availability of the combined remedies of injunction and astreinte in more recent years has changed the character of much litigation against the state. On the other hand, the distinctive administrative law procedures have helped the citizen, especially where the interests of the citizen overlap with the interests of good administration in maintaining the

81 Cf. Gillick v Norfolk and Wisbech AHA [1986] A.C.112, where a challenge was permitted against a circular from the Ministry of Health to general practitioners about the prescription of contraceptives to girls under the legal age of consent. 
legality of actions by officials. For example, the early availability of the standing of associations allowed the pooling of resources and collective redress.

Recent procedural developments have led more often to an expansion of the scope of judicial review. The broadening of the standing rules in relation to interest groups has been of particular importance. The availability of the référé-liberté and the power of injunction have enabled interest groups to have speedy redress against administrative decisions. Single-interest pressure groups now find judicial review an important political weapon, particularly in protecting minorities against policies which may be popular with the majority. The long-standing role of GISTI in protecting the interests of migrants is an obvious example. But, during the Covid-19 pandemic, administrative law litigation provided churches with an avenue to challenge limitations on the freedom of religion. Pressures for broader uses of judicial review have been helped by the movement towards recognising fundamental rights, especially through the ratification of the European Convention on Human Rights in 1974. The use of that Convention to challenge administrative actions against prisoners or in schools or even in the military has provided minorities a forum in which to voice concerns about the actions of the majority. Though procedural reforms often appear technical, they have the potential for major impacts on the way protest is conducted in society. 